\title{
THE EFFECT OF 17 $\alpha$-METHYLTESTOSTERONE HORMONE APPLICATION ON MASCULINIZATION AND GROWTH RATE OF VANAME SHRIMP LARVAE (LITOPENAEUS VANNAMEI, BOONE 1931)
}

\author{
Saleh Sahlan M.* \\ Master's Degree Program, Faculty of Fisheries and Marine Sciences, \\ Univrsity of Brawijaya, Indonesia \\ Widodo Maheno Sri, Kilawati Yuni \\ Faculty of Fisheries and Marine Sciences, University of Brawijaya, Indonesia \\ *E-mail: $\underline{\text { humas@ub.ac.id }}$
}

\begin{abstract}
Sustainable development of Vaname shrimp aquaculture in the future depends on several things, one of which is the availability of the male parent in a sufficient quantity. Regarding this problem, sex reversal can be performed as the solution. Sex reversal is a technique of sex genetic differentiation to change sexes artificially from males genetically into phenotype females or vice versa. This research was intended to obtain the maximal mono-sex (single sex) male of Vaname shrimp using 17a-methyltestosterone (MT) hormone through sex reversal technology to the limited sex change in Vaname shrimp, in which to date the Vaname male parent gained is still dependent on natural selection. This research used a descriptive and experimental method. The experimental research design used was a completely randomized design (RAL - Rancangan Acak Lengkap). The treatment given was immersing the shrimp larvae in 17a-methyltestosterone (MT) for 8 hours at different doses of $0 \mathrm{mg} / \mathrm{L}, 5 \mathrm{mg} / \mathrm{L}, 8 \mathrm{mg} / \mathrm{L}$, and $12 \mathrm{mg} / \mathrm{L}$. The immersion of the post-larvae (PL1) of Vaname shrimp using the 17a-methyltestosterone hormone gave a significant result $(P<0.05)$ on all of the treatments and control in which the highest percentage of male Vaname shrimp was obtained from the treatments with $8 \mathrm{mg} / \mathrm{L}$ and $12 \mathrm{mg} / \mathrm{L}$ doses, respectively reaching $64 \%$ and $66.7 \%$. As for the weight growth, the immersion of the post-larvae (LP1) growth of Vaname shrimp using 17a-methyltestosterone hormone provided a very significant result $(P<0.05)$ on all the treatments and control in which the highest weight growth (weight gain) and Specific Growth Rate of Body Weight (SGR BW) were shown by the treatments with $8 \mathrm{mg} / \mathrm{L}$ and $12 \mathrm{mg} / \mathrm{L}$ doses, respectively reaching 1.5415 grams and 1.5871 grams.
\end{abstract}

\section{KEY WORDS}

17a-methyltestosterone, masculinization, Litopenaeus vannamei, post-larvae.

Shrimp is one of the export commodities with a high economic value and great demand by the world market. Production of shrimp, especially Vaname shrimp, is always increasing every year, especially Vaname shrimp. Vaname shrimp is an introduced shrimp originating from the western coast of Latin America and has been successfully cultivated in Indonesia. Production of Vaname shrimp during $2010-2014$ increased by $20.49 \%$ from 206.578 tons to 411.729 tons (the Ministry of Maritime Affairs and Fisheries, 2014).

Fishery aquaculture activities, especially shrimp farming, continue to be developed in Indonesia due to the increased consumer demand from time to time, that is to meet the needs of export markets. The world market's high demand in this commodity is a potential opportunity for Indonesia's natural resources to increase the country's foreign exchange value from the aquaculture sector.

The sustainable development of shrimp aquaculture in the future highly depends on several things, including the availability of male Vaname shrimp in a sufficient quantity. So far, male Vaname shrimp is still dependent on natural selection, causing the existence of Vaname male parent is on a limited scale. In order that Vaname parent still continues to exist 
in the future, a breeding program needs to carry out. Such a program is hoped to make the availability of Vaname male parent no longer depend on natural selection. In line with this, sex reversal can be one means that provides a solution to the problem. Sex reversal is a technique of sex genetic differentiation to change sexes artificially from males genetically into phenotype females or vice versa. Changes in sex can occur naturally and artificially.

Physiologically, fish sexes can be directed or determined by using steroid hormones. In a simple, hormone administration aims to influence the balance of hormones in the blood that, at the time of sex differentiation, is very determining whether a particular individual will be male or female, in which the hormone is injected from outside the body Sumantadinata and Carman (1995). This research aimed to obtain the maximal mono-sex (single sex) male of Vaname shrimp using 17a-methyltestosterone (MT) hormone through post-larvae immersion - sex reversal technology to the limited sex change in Vaname shrimp, in which to date the Vaname male parent gained is still dependent on the natural selection. Therefore, as an alternative to solve the problem, it is necessary to conduct relevant research soon so that the Vaname male population no longer depends on nature.

\section{MATERIALS AND METHODS OF RESEARCH}

Research Material. The tools used in this research were concrete tubs, aerator, hoses and aeration stones, camera, duster, tissue, electric microscope, petri dish, a digital scale, caliper, measuring cups, refrigerator, basins/ washbowls, thermometer, DO meter, pH meter, and refractometer.

The materials used in this research were post-larvae of Vaname shrimp (Litopenaus vannamei), post-larva feed, Methyltestosterone hormone, ethanol of $70 \%$, formalin of $10 \%$, Aquadest, hematoxylin and label paper.

Test Animal Preparation. The test animals used in this research were 1-day old postVaname shrimp larvae (Litopenaues vannamei) originating from the Production Center of Parent of Superior Shrimp and Mollusk (Balai Produksi Induk Udang Unggul dan Kekerangan - BPIU2K), Karangasem, Bali. The post-larva selection was done morphologically based on its morphological features such as length, weight, organ completeness, and body color. The acclimatization did not require a long time because the Vaname shrimp examined came from the same place, namely BPIU2K.

Test Animal Immersion into 17a-methyltestosterone hormone solution. The post-larvae $(\mathrm{PL})$ of Vaname shrimp were randomly selected and stocked into immersion aquariums with a density of $10 \mathrm{PL} / \mathrm{L}$, so the total post-larvae stocked in each aquarium was 100 post-larvae $(\mathrm{PL})$. The immersion process was performed for 8 hours at doses of $0 \mathrm{mg} / \mathrm{L}, 4 \mathrm{mg} / \mathrm{L}, 8 \mathrm{mg} / \mathrm{L}$, and $12 \mathrm{mg} / \mathrm{L}$ with three replications. After that, the post-larvae were filtered and re-stocked in an aquarium containing 10 liters of new seawater. The control treatment was prepared without the addition of 17a-methyl testosterone hormone.

Test Animal Rearing. The rearing of the post-Vaname shrimp larvae (Litopenaus vannamei) was carried out in 12 units of aquarium container, each of which contained 10 liters of water with a density of $10 \mathrm{PL} /$ liter, so the total post-larvae stocked in each aquarium amounted to 100 post-larvae $(P L)$. The rearing was done indoors to make the change between night and day not too significant so that the post-larvae were not stressed by temperature changes. Substitution of water as the maintenance media was done every two days as much as $60-70 \%$ by being siphoned using a small hose and then replaced with clean and sterilized fresh water. At the end of the rearing period, namely PL60, the post-larvae in each aquarium were collected by means of siphoning the water first, and then the collected post-larvae from each aquarium were weighed for the purpose of growth rate analysis.

Determination of sex and sex ratio. Observation of the post-Vaname shrimp larvae given 17a-methyltestosterone hormone treatments through immersion was done at the end of the research. The female post-larvae were characterized by a thelycum which is described as a small indentation between the fourth and fifth walking legs on both sides. Meanwhile, the male post-larvae were characterized by the appendix masculine on a pair of the second natatorial (swimming) legs and the gonophores complex on the fifth walking legs. 
Percentage of Weight Growth. At the end of the test, each individual of the post-larvae from each group treatment was weighed and measured to determine the body weight. From the body weight measurement, the average of the final body weight (BW) and specific growth rate (SGR) were calculated. The body weight was measured using a digital scale with a precision of 0.0001 gram.

Statistical Analysis. One analysis of variance direction (ANOVA) was used to determine the difference between the treatments. Duncan test was also conducted to determine the significance of the difference between the treatments. The significance level of the results was set at $P<0.05$. All the statistics were performed using SPSS (version 16).

\section{RESULTS AND DISCUSSION}

Percentage of Male Vaname Shrimp (Litopenaeus vannamei). In this research, the identification of male Vaname shrimp was performed after 60 days of rearing, in which the post-Vaname shrimp larvae were randomly selected and stocked into immersion aquariums with a density of $10 \mathrm{PL} /$ liter, so the total post-larvae stocked in each aquarium was $100 \mathrm{PL}$. The immersion process was performed for 8 hours at doses of $0 \mathrm{mg} / \mathrm{L}, 4 \mathrm{mg} / \mathrm{L}, 8 \mathrm{mg} / \mathrm{L}$, and $12 \mathrm{mg} / \mathrm{L}$ with three replications. Furthermore, the rearing was done for 60 days to prevent the identification from the occurrence of errors. To determine the percentage of male postVaname shrimp larvae, the external sex was identified using a microscope.

Based on the observed percentage of male Vaname shrimp, the treatments of $17 \alpha-$ methyltestosterone hormone administration with different doses resulted in a higher percentage of male Vaname shrimp compared with that without the 17a-methyltestosterone hormone administration or the control. The observation data on the percentage of male Vaname shrimp at the end of this research can be seen in the following table and figure.

Table 1 - Ratio Percentage of Male Vaname Shrimp (Litopenaeus vannamei) on Various Treatments and Control

\begin{tabular}{|c|c|c|c|c|}
\hline \multirow{2}{*}{ Immersion Duration } & \multicolumn{4}{|c|}{ Doses of 17a-methyltestosterone Hormone } \\
\cline { 2 - 5 } & $0 \mathrm{Mg} / \mathrm{L}$ & $4 \mathrm{mg} / \mathrm{L}$ & $8 \mathrm{mg} / \mathrm{L}$ & $12 \mathrm{mg} / \mathrm{L}$ \\
\hline 8 Hours & $54.7 \pm 2.1^{\mathrm{a}}$ & $61.7 \pm 2.1^{\mathrm{b}}$ & $64 \pm 4.0^{\mathrm{bc}}$ & $66.7 \pm 2.3^{\mathrm{C}}$ \\
\hline
\end{tabular}

The data shown are the mean \pm standard deviation.

The letters denote Duncan Test difference.

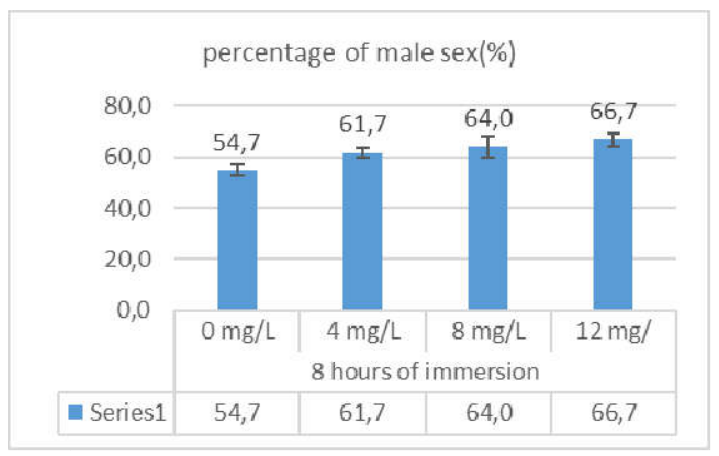

Figure 1 - Graph of Ratio Percentage of Male Vaname Shrimp on Various Treatments and Control

Based on the data above, it can be seen that the post-Vaname shrimp larvae (PL1) immersion using 17a-methyltestosterone hormone showed a significant result $(P<0.05)$ on all the treatments and control in which the highest percentage of male Vaname shrimp was obtained from the treatments with $8 \mathrm{mg} / \mathrm{L}$ and $12 \mathrm{mg} / \mathrm{L}$ doses, respectively achieving $64 \%$ and $66.7 \%$. The $17 \alpha$-methyltestosterone hormone containing steroids is an androgenic hormone, thus causing an increase in testosterone levels in the body of Vaname shrimp so as to generate masculinizing effects. According to Donaldson et al. (1978), steroids are hormones that can affect the reproduction of animals, stimulate the growth and differentiation 
of genitals, as well as affect the behavior of fish and shrimp. Meanwhile, androgen hormones function to determine male sex and behavior, testicular development, sperm ducts and normal cleavage process of spermatogenesis.

Several factors affecting the success of sex reversal are size and age, duration of treatment, environment (Phelps and Popma, 2000), fish species, genetic, hormonal type, hormone dose, treatment time, (Dunham, 2004). Meanwhile, Touir (1977) stated that sex reversal on Macrobrachium rosenbergii will be achieved well if done in the initial stadia before the formation of gonads. According to Charniaux-Cotton (1954), Hasegawa et al. (1993), and Touir (1977), androgen hormones produced by the androgenic gland are responsible for influencing the development of primary and secondary male sexual characteristics in crustaceans.

Weight Growth of Vaname Shrimp. Based on the observed weight growth (weight gain) percentage of post-Vaname shrimp larvae, the treatments of the 17a-methyltestosterone hormone administration with different doses resulted in a higher weight percentage of male Vaname shrimp compared to that without the 17a-methyltestosterone hormone administration or the control. The observation data of the weight growth percentage of male Vaname shrimp at the end of this research can be completely seen in the following table and figure.

Table 2 - Ratio Percentage of Weight Growth and Specific Growth Rate of Body Weight (SGR BW) of Vaname Shrimp (Litopenaeus vannamei) on Various Treatments and Control

\begin{tabular}{|c|c|c|c|c|}
\hline \multirow{2}{*}{ Immersion Duration } & \multicolumn{4}{|c|}{ Doses of $17 \alpha$-methyltestosterone Hormone } \\
\hline & $0 \mathrm{Mg} / \mathrm{L}$ & $4 \mathrm{mg} / \mathrm{L}$ & $8 \mathrm{mg} / \mathrm{L}$ & $12 \mathrm{mg} / \mathrm{L}$ \\
\hline 8 Hours & $1.3601 \pm 0.0139^{a}$ & $1.4601 \pm 0.0267^{\mathrm{D}}$ & $1.5415 \pm 0.0105^{\mathrm{C}}$ & $1.5872 \pm 0.0104^{d}$ \\
\hline
\end{tabular}

The data shown are the mean \pm standard deviation.

The letters denote Duncan Test difference.

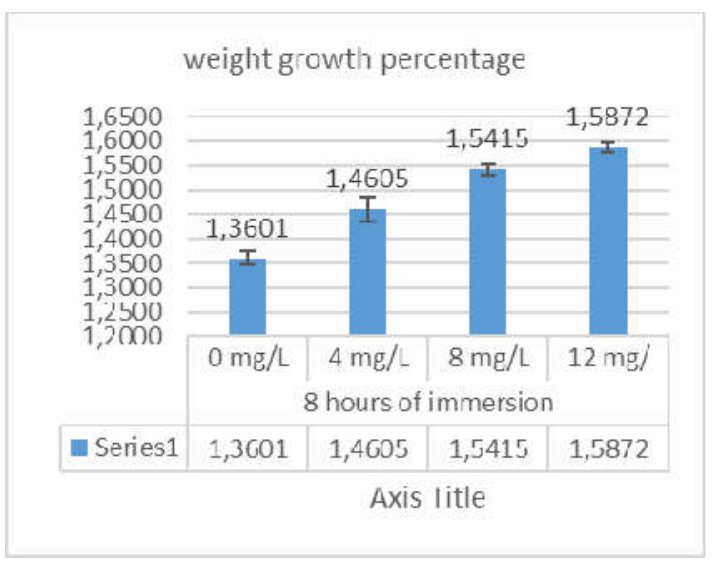

Figure 2 - Graph of Ratio Percentage of Vaname Shrimp Weight Growth on Various Treatments and Control

From the table and graph above, it is known that the post-Vaname shrimp larvae (PL1) immersion using 17a-methyltestosterone hormone showed a very significant result $(P<0.05)$ on all the treatments and control in which the highest weight growth (weight gain) and specific growth rate of body weight (SGR BW) were obtained from the treatments with 8 $\mathrm{mg} / \mathrm{L}$ and $12 \mathrm{mg} / \mathrm{L}$, respectively reaching 1.5415 grams and 1.5871 grams. The increasing weight growth average of Vaname shrimp larvae if compared to the control in this research indicates that the 17a-methyltestosterone hormone administration through immersion has been able to provide an effective effect on the weight growth of Vaname shrimp. This is consistent with Piferrer (2001) stating that the treatment of steroid hormones, in addition to affecting genital changes, can also have an impact on growth. According to Anthony et al. (1999), steroid hormones are greatly useful in protein synthesis in muscle formation. Meanwhile, Fulierton (1980) explained that, in addition to having androgenic properties, it 
turns out that testosterone has anabolic properties, which can stimulate muscle growth. Because the concentration of dissolved synthetic hormones that enter the shrimp body is different, shrimps that absorb hormones with high concentrations grow much faster than other shrimps.

\section{CONCLUSION}

Based on the findings of this research, the use of $17 \alpha$-methyltestosterone hormone through immersion can increase the male Vaname shrimp percentage by $66.7 \%$ and the weight growth percentage by 1.5872 grams.

\section{REFERENCES}

1. Anthony JC, Anthony TG, Layman DK. 1999. Leucine supplementation enhance skeleton muscles recovery in rats following exercise. The journal of nutrition 129: 1102-1106

2. Charniaux-Cotton H. 1954. De'couverte chez un Crustace' Amphipode (Orchestia gamarella) dÿune glande endocrine responsable de la diffe'renciation des caracte'res sexuels primaires et secondaires ma^les. CR. Acad. Sci. Paris 239:780-782.

3. Donaldson, EM., UH.M. Fagerlund, D.A. Higgs and J.R. Bride. 1978. Hormonal Enhancement of Growth, p: 456-597. In Fish Physiology (W.S. Hoar, D.J. Randall and J.R. Brett, eds.), Vol. VIII. NY: Academic Press

4. Dunham, R.A. 2004. Aquaculture and Fisheries Biotechnology: Genetic Approaches. CABI Publ. Cambridge, USA.

5. Fulierton DS. 1980. Steroid dan senyawa terapetik sejenis. Buku teks Wilson dan Gisvold. Kimia farmasi dan medicinal organik. Editor: Doerge RF. Edisi VIII, bagian II. J.B. Lippincott Company. Philadelphia-Toronto. USA, pp. 675-754.

6. Hasegawa Y, Hirose E, Katakura Y. 1993. Hormonal control of sexual differentiation and reproduction in crustacea. Oxford Journals. American Zoologist. 33(3):403-411.

7. Kementerian Kelautan dan Perikanan. 2014. Laporan Kinerja Kementrian Kelautan dan Perikanan. Jakarta (ID).

8. Phelps RP dan Thomas JP. 2000. Sex Reversal of Tilapia. Page 34-59 in B.A. CostaPierce and J.E. Rakocy, eds. Tilapia Aquaculture in the Americas, Vol 2. The World Aquaculture Society, Baton Rounge, Louisiana, United States.

9. Piferrer, F., 2001, "Endocrine Sex control Strategies for Feminization of Teleost Fish" Aquaculture 197: 229-281.

10. Popma, T.J dan Lovshin LL. 1999. Worldwide Prospect for Commercial Production of Tilapia. Research and Development Series No. 41. International Center for aquaculture and Aquaric Environments. Departemen of Fisheries and Allied Aquaculture Auburn University. Alabama.

11. Touir A. 1977. Donne'es nouvelles concernant endocrinology esexuelle des Crustace's De'capodes Natantia hermaphrodites et gonochoriques. I. Maintien des glandes androge'nes et role de ces glandes dans le controle des game'togene'ses et des caracte'res sexuels xternes males. Bull. Soc. Zool. Fr.102:375-400. 